\title{
Genetic identification of bucktooth parrotfish Sparisoma radians (Valenciennes, 1840) (Labridae, Scarinae) by chromosomal and molecular markers
}

\author{
Fabilene Gomes Paim ${ }^{1}$, José Henrique Souza Galdino Brandão ${ }^{1}$, Iracilda Sampaio ${ }^{2}$, \\ Paulo Roberto Antunes de Mello Affonso ${ }^{1}$ and Débora Diniz ${ }^{1}$ \\ ${ }^{I}$ Departamento de Ciências Biológicas, Universidade Estadual do Sudoeste da Bahia, Jequié, BA, Brazil. \\ ${ }^{2}$ Instituto de Estudos Costeiros, Universidade Federal do Pará, Bragança, PA, Brazil.
}

\begin{abstract}
Parrotfishes (Labridae, Scarinae) comprise a large marine fish group of difficult identification, particularly during juvenile phase when the typical morphology and coloration of adults are absent. Therefore, the goal of this study was to test cytogenetic markers and DNA barcoding in the identification of bucktooth parrtotfish Sparisoma radians from the northeastern coast of Brazil. Sequencing of cytochrome c oxidase subunit I (COI) confirmed all studied samples as S. radians, and all showed high similarity (99-100\%) with Caribbean populations. The karyotype of this species was divergent from most marine Perciformes, being composed of $2 n=46$ chromosomes. These consisted of a large number of metacentric and submetacentric pairs with small amounts of heterochromatin and GC-rich single nucleolar organizer regions (NORs) not syntenic to $5 \mathrm{~S}$ rDNA clusters. These are the first data about DNA barcoding in parrotfish from the Brazilian province and the first refined chromosomal analysis in Scarinae, providing useful data to a reliable genetic identification of $S$. radians.
\end{abstract}

Keywords: COI, karyotype, South Atlantic fish, ribossomal genes, Robertsonian rearrangements.

Received: May 13, 2014; Accepted: July 28, 2014.

Scarinae (Labridae) encompasses about 10 genera and 99 species of marine fish, popularly known as parrotfish (Helfman et al., 2009; Parenti and Randall, 2011). The members of this subfamily are widespread throughout tropical zones of the Pacific, Indian and Atlantic oceans and play a key role in ecology and fisheries of reefs (Bellwood, 1994; Streelman et al., 2002; Robertson et al., 2006).

Traditionally, this group has been classified as a family (Scaridae) derived from Labridae (Schultz, 1958; Bellwood, 1994). Nonetheless, molecular studies revealed that Labridae+Scaridae compose a monophyletic group, and parrotfishes were reallocated as a subfamily (Scarinae) of Labridae (Westneat and Alfaro, 2005).

The parrotfishes include some of the most colorful and typical representatives of coastal reefs (Streelman et al., 2002). Indeed, some Scarinae species are morphologically identical, and coloration has been useful to distinguish them, as reported within the genus Sparisoma (Gasparini et al., 2003; Robertson et al., 2006; Pinheiro et al., 2010; Rocha et al., 2012). Seven out of the 15 Sparisoma species are reported to exist in sympatry along the Brazilian coast

Send correspondence to Paulo Roberto Antunes de Mello Affonso. Departamento de Ciências Biológicas, Universidade Estadual do Sudoeste da Bahia, Av. José Moreira Sobrinho s/n, 45206-190 Jequié, BA, Brazil. E-mail: paulomelloaffonso@yahoo.com.br.
(S. atomarium, S. amplum, S. axillare, S. frondosum, S. radians, $S$. rocha and $S$. tuiupiranga), including recent descriptions based on morphological traits (Moura et al., 2001; Gasparini et al., 2003; Feitoza et al., 2005; Pinheiro et al., 2010; Rocha et al., 2012).

Nonetheless, the color patterns commonly used to a precise identification of Sparisoma species are best observed in fresh specimens only, and they might vary according to sex and ontogenetic state (Bernardi et al., 2000). Thus, the utilization of genetic markers should represent an efficient and reliable tool to identify these species, independent of the morphological aspects. Accordingly, sequencing of a portion of the COI gene has proven to be efficient in DNA barcoding at the species level in marine fish (Hubert et al., 2010; Weigt et al., 2012; Veneza et al., 2013). Furthermore, chromosomal analyses in fish species can potentially provide informative markers for cytotaxonomy (e.g., Medrado et al., 2012).

In the case of Labridae, cytogenetic studies have shown that Robertsonian rearrangements and pericentric inversions accounted for the divergent karyotypes in several species when compared to the plesiomorphic condition for marine Perciformes ( $2 \mathrm{n}=48$ acrocentric chromosomes) (Sena and Molina, 2007a, 2007b; Molina et al., 2012a). On the other hand, chromosomal data in Scarinae are available 
for only two Atlantic species: Sparisoma axillare and Scarus trispinosus (Sena and Molina, 2007b).

Therefore, the goal of this study was to evaluate the applicability of chromosomal markers and DNA barcoding for the identification of Sparisoma radians from the Brazilian coast. In addition, more refined methods of chromosomal analyses were carried out to be added to the karyotypic data available for Scarinae and further inferences about chromosomal evolution in parrotfish.

Five individuals of Sparisoma radians (three females and two juveniles of undetermined sex) were collected in Camamu Bay at the southern coast of Bahia, Brazil. Mitotic chromosomes were obtained based on the procedure described by Netto et al. (2007). Heterochromatin and active NORs were detected by C-banding (Sumner, 1972) and silver nitrate staining (Howell and Black, 1980), respectively. Base-specific fluorochrome staining (Schweizer, 1980) was used to reveal GC-rich and AT-rich regions.

The 18S and 5S rDNA cistrons were simultaneously mapped on chromosomes by fluorescence in situ hybridization (double-FISH) as proposed by Pinkel et al. (1986), with a stringency level of $77 \%$. Ribossomal probes were obtained via PCR according to Hatanaka and Galetti Jr (2004) for 18S rDNA and Martins et al. (2006) for 5S rDNA. The $18 \mathrm{~S}$ rDNA probe was labeled with biotin16-dUTP and signals were detected by fluorescein-conjugated avidin (FITC) while 5S rDNA probes were labeled with digoxygenin-11-dUTP and detected by a anti-digoxygenin-rhodamine system (Roche Applied Science). Chromosomes were counterstained with 4,6-diamidino-2phenylindole (DAPI) included in Vectashield mounting medium (Vector).

Micrographs were captured using epifluorescence Olympus BX-51 and Olympus BX-61 microscopes equipped with Image Pro-Plus v. 6.2. software (Media Cybernetics), followed by edition in Adobe Photoshop v. 7.0. The karyotypes were organized based on chromosomal measurements and classified as proposed by Levan et al. (1964).

For DNA barcoding, total DNA was extracted from liver or muscle tissue using the Wizard Genomic DNA Purification kit (Promega) according to the manufacturer's instructions. A fragment of nearly $650 \mathrm{bp}$ at the 5 ' end of COI was amplified via PCR using the primers Fish F2 5'TCGACTAATCATAAAGATATCGGCAC-3' and Fish R2 5'ACTTCAGGGTGACCGAAGAATCAGAA-3' (Ward et al., 2005). Each reaction comprised $0.2 \mathrm{mM}$ of dNTPs, 1x PCR buffer, $2 \mathrm{mM}$ of $\mathrm{MgCl}_{2}, 0.4 \mu \mathrm{M}$ of each primer, $0.7 \mathrm{U}$ of Taq DNA polymerase, 50 to $100 \mathrm{ng}$ of template DNA and ultrapure water to a final volume of $15 \mu \mathrm{L}$. The PCR protocol consisted of an initial step at $95{ }^{\circ} \mathrm{C}$ for 5 min, 35 cycles of $40 \mathrm{~s}$ at $94{ }^{\circ} \mathrm{C}, 40 \mathrm{~s}$ at $55^{\circ} \mathrm{C}$ and $40 \mathrm{~s}$ at $72{ }^{\circ} \mathrm{C}$, and a final extension step for $7 \mathrm{~min}$ at $72^{\circ} \mathrm{C}$. Subsequently, the reaction products were purified and sequenced in an ABI 3500XL Genetic Analyzer automatic sequencer
(Applied Biosystems). All sequences were deposited in the Barcode of Life Database (BOLD) platform (http://www.boldsystems.org) along with details of collected specimens and identified as HG3012/BAHIA-102-14, HG3015/BAHIA-105-14, HG3017/BAHIA-106-14, HG3029/BAHIA-117-14, and HG3014/BAHIA-118-14.

The sequences were then submitted to BLAST (basic alignment search tool) searches in the NCBI (National Center for Biotechnology Information) database to check putative homologies with other sequences and confirmation of taxonomic identification of the samples. Using ClustalW Multiple Alignment in the software BioEdit, the obtained sequences were aligned with six COI sequences available in GenBank (NCBI) for Caribbean samples of $S$. radians (access numbers JQ839590, JQ839899), as well as $S$. cretense (KC501552, GQ341598), S. chrysopterum (JQ841012) and S. rubripinne (GU225442). The aligned sequences (about $650 \mathrm{bp}$ ) were exported to Mega v.5 (Tamura et al., 2011) to generate a genetic distance matrix and a tree topology using Neighbor-Joining (NJ) algorithm and the Kimura-2-parameter substitution model, with 1000 bootstrap replications.

The similarity levels of the five COI sequences obtained in the present study and those available in GenBank for specimens of Sparisoma radians from the Caribbean (Weigt et al., 2012 and unpublished data) ranged from 99 to $100 \%$. As a result, the NJ tree clustered both Brazilian and Central America specimens of $S$. radians apart from $S$. rubripinne, $S$. cretense and $S$. chrysopterum (Figure 1). The mean distance within $S$. radians was $0.2 \%$, while the distance values of this group in relation to $S$. cretense, $S$. chrysopterum and S. rubripinne were equal to $11.9,12.9$ and $14 \%$, respectively. Therefore, the COI sequences efficiently distinguished Sparisoma species, including samples from the closely related $S$. radians (present study, Weigt et al., 2012) and S. rubripinne (Valdez-Moreno et al., 2010)

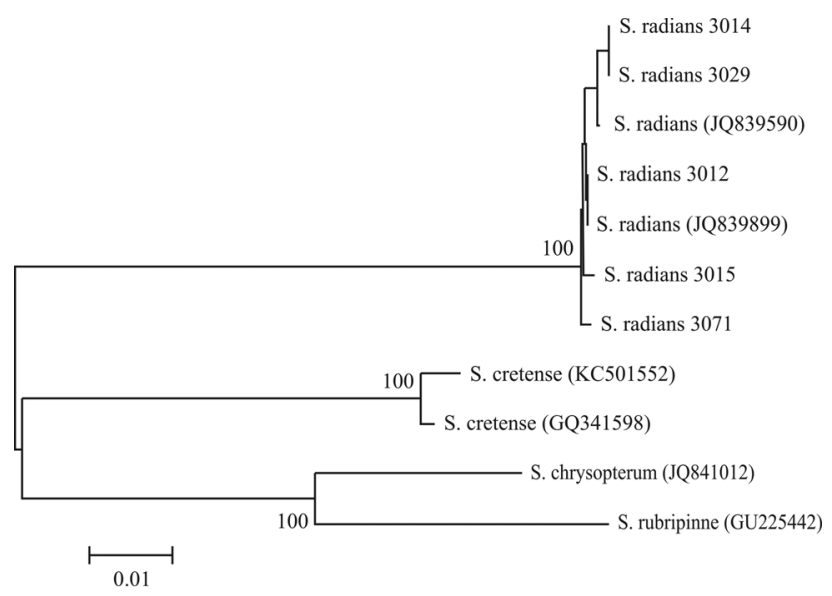

Figure 1 - Neighbor-Joining tree of COI sequences comparing $S$. radians from Brazilian coast and other populations and species of Sparisoma. The numbers in parentheses refer to GenBank database (see text for details). 
by revealing a barcode gap largely superior to 10 times the mean intraspecific variation, as recommended by Hebert et al. (2003).

All specimens of $S$. radians shared a diploid number of $2 \mathrm{n}=46$ and a karyotype composed of 24 meta-submetacentric (m/sm) and 22 subtelo-acrocentric (st/a) chromosomes (Figure 2A). Heterochromatin was distributed over pericentromeric regions of most chromosomes and telomeric regions on the short arms of pair 14 (Figure 2B). Ag-NORs were located at terminal position on the short arms of pair 14 (Figure 2C), interspersed with GC-rich heterochromatin segments that were positively stained by chromomycin $\mathrm{A}_{3}\left(\mathrm{CMA}_{3}\right)$ (Figure 2D).

The physical mapping of $18 \mathrm{~S}$ and 5S rDNA cistrons revealed non-synteny between both the ribossomal genes (Figure 3). As expected, the location of 18S rDNA sites was overlapping with Ag-NORs, confirming the existence of a single NOR-bearing pair in S. radians. The $5 \mathrm{~S}$ rRNA genes were located at interstitial region on the smallest chromosomal pair (Figure 3).

The karyotypic pattern of $S$. radians $(2 n=46)$ is very similar to that reported for $S$. axillare (Table 1), suggesting a differentiated karyoevolution pathway of parrotfishes (Galetti Jr et al., 2006). The chromosomal number and the presence of large metacentric pairs in the few species of Sparisoma analyzed so far also contrasts with the numerical conservativeness $(2 \mathrm{n}=48)$ observed in Scarus and other Labridae subfamilies, such as Bodianinae and Corinae (Table 1).

A reduced $2 \mathrm{n}$ value combined with a large number of biarmed chromosomes in Sparisoma, including S. radians, indicates that both Robertsonian rearrangements and pericentric inversions took place during karyoevolution in this group. Actually, inversions have been commonly reported in Labridae from the South Atlantic, leading to increased fundamental arm numbers and conserved diploid values (Table 1). On the contrary, fusions are rarely observed in marine fish and, thus, the presence of large metacentric pairs associated with lower $2 \mathrm{n}$ values in relation to basal

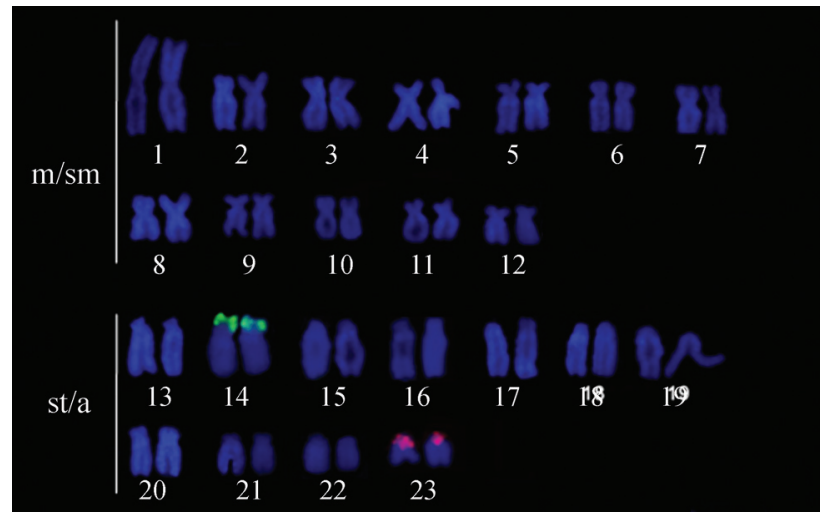

Figure 3 - Distribution of 18S rDNA (in green) and 5S rDNA (in magenta) in DAPI-stained karyotype of S. radians after double-FISH.

karyotype $(2 \mathrm{n}=48)$ can be interpreted as a synapomorphic feature of Sparisoma (Table 1). Considering that, in spite of identical $2 n$ values, the fundamental number in $S$. radians was higher than that reported in S. axillare (Sena and Molina, 2007a), we infer that the former has undergone additional pericentric inversions and should be placed as a more derived species than the latter.

The presence of single NORs is regarded as a basal and widespread trait in Perciformes (Galetti Jr et al., 2006), including $S$. radians. Likewise, other labrids (Molina et al., 2012b), including Scarinae (Sena and Molina, 2007a), share a single NOR-bearing pair. However, multiple NORs seem to be an apomorphic feature in the subfamily Corinae, as reported in Halichoeres poeyi, H. radiatus (Sena and Molina, 2007b) and Coris julis (Mandrioli et al., 2000). The NOR-bearing pair of $S$. radians (pair 14) seems to be homeologous to that observed in S. axillare (pair 11) (Sena and Molina, 2007a), given their similarity in type, size and location of NORs.

Heterochromatin in fish chromosomes is usually distributed over centromeric and pericentromeric regions in several marine fish groups such as Gobiidae (Lima-Filho et al., 2012), Haemulidae (Motta-Neto et al., 2011a, 2011b),

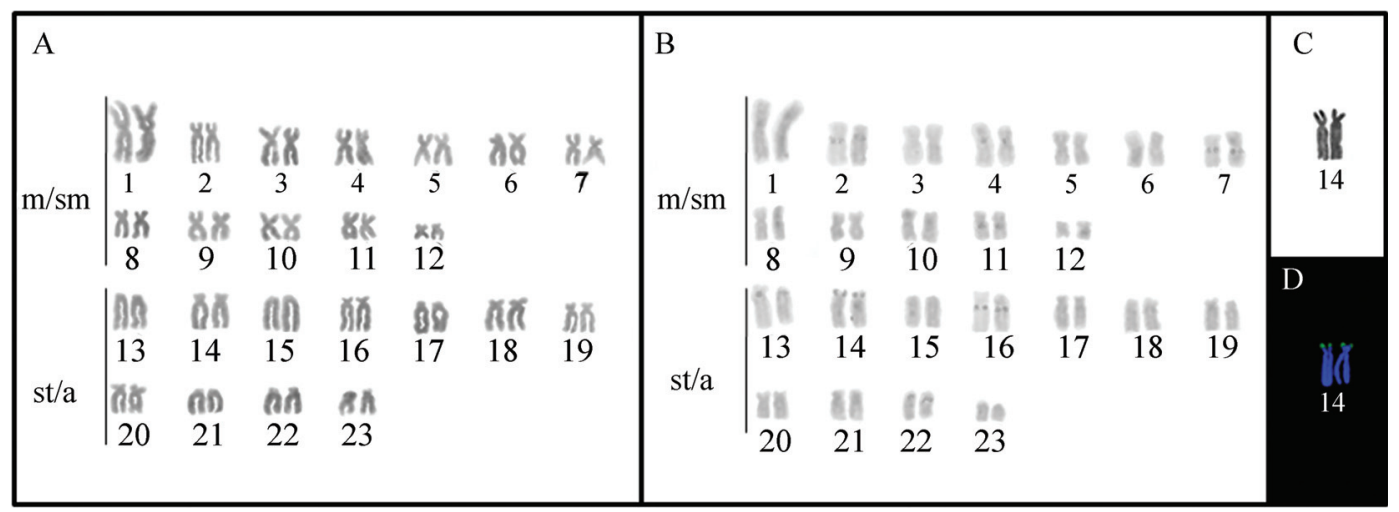

Figure 2 - Karyotype of Sparisoma radians $(2 \mathrm{n}=46)$ after Giemsa staining $(\mathrm{A})$ and C-banding $(\mathrm{B})$. The NOR-bearing pair is shown in detail after silver nitrate (C) and fluorochrome staining (D) revealing $\mathrm{CMA}_{3}{ }^{+}$sites coincident with NORs. 
Table 1 - Cytogenetic data in Labridae from South Atlantic.

\begin{tabular}{|c|c|c|c|c|c|c|}
\hline Species & $2 n$ & Karyotype & FN & C-banding & $\mathrm{Ag}-\mathrm{NOR}$ & Reference \\
\hline \multicolumn{7}{|l|}{ Bodianinae } \\
\hline Bodianus rufus & 48 & $6 m+12 s m+14 s t+16 a$ & 80 & cen, per & $10 \mathrm{p}$ & Molina et al., 2012b \\
\hline Bodianus pulchellus & 48 & $4 m+12 s m+14 s t+18 a$ & 78 & cen, per & $9 \mathrm{p}$ & Molina et al., 2012b \\
\hline Bodianus insularis & 48 & $4 m+12 s m+14 s t+18 a$ & 78 & cen, per & $9 p$ & Molina et al., 2012b \\
\hline \multicolumn{7}{|l|}{ Corinae } \\
\hline Halichoeres brasiliensis & 48 & $48 \mathrm{a}$ & 48 & cen, per & $9 \mathrm{q}$ & Sena and Molina, 2007a \\
\hline Halichoeres poeyi & 48 & $4 m+44 s t$ & 52 & cen, per & 1-2 a pairs & Sena and Molina, 2007a \\
\hline Halichoeres radiatus & 48 & $48 \mathrm{a}$ & 48 & cen, per & 2 a pairs & Sena and Molina, 2007a \\
\hline \multicolumn{7}{|l|}{ Scarinae } \\
\hline Scarus trispinosus & 48 & $6 \mathrm{~m}+10 \mathrm{sm}+24 \mathrm{st}+8 \mathrm{a}$ & 88 & cen, per & $9 p$ & Sena and Molina, 2007b \\
\hline Sparisoma axillare & 46 & $6 m+14 s m+4 s t+22 a$ & 70 & cen, per & $11 \mathrm{p}$ & Sena and Molina, 2007b \\
\hline Sparisoma radians & 46 & $24 \mathrm{~m} / \mathrm{sm}+22 \mathrm{st} / \mathrm{a}$ & 84 & cen, per, ter & $14 \mathrm{p}$ & Present study \\
\hline
\end{tabular}

$2 \mathrm{n}=$ diploid number; $\mathrm{FN}=$ fundamental number; $\mathrm{m}=$ metacentric; $\mathrm{sm}=$ submetacentric; $\mathrm{st}=$ subtelocentric; $\mathrm{a}=\mathrm{acrocentric} ;$ cen $=$ centromeric; per $=$ pericentromeric; $\mathrm{t}=$ terminal; $\mathrm{p}=$ short arms; $\mathrm{q}=$ long arms.

Carangidae (Accioly et al., 2012; Jacobina et al., 2012) and Grammatidae (Molina et al., 2012a). Following this trend, $S$. radians was characterized by a preferential distribution of C-bands close to centromeres, in addition to a terminal GC-rich heterochromatin segment equivalent to NORs on pair 14 (Figure 2). As this is the first report about GC content in Scarinae, further inferences can currently not be made, even though the pattern herein described agrees with that observed in other labrids of the subfamily Bodianinae (Molina et al., 2012b).

Similarly, the present study provides the first data concerning the location of $18 \mathrm{~S}$ and $5 \mathrm{~S}$ ribosomal genes in parrotfishes. The lack of synteny of each rDNA class suggests an independent evolution of the two ribosomal gene families (Pendás et al., 1993). As expected, 18S rDNA clusters in $S$. radians were coincident with Ag-NORs and $\mathrm{CMA}_{3}{ }^{+}$regions, supporting the occurrence of single NORs as a basal condition of Labridae (Molina et al., 2012b). The interstitial location of 5S rDNA on long arms, as observed in $S$. radians, is also considered an ancestral trait of teleosteans (Martins and Galetti Jr, 2001; Martins and Wasko, 2004). On the other hand, the presence of a single pair bearing 5S rRNA genes, as reported in the studied species, is a less frequent condition in fish (Martins et al., 2011). Unfortunately, there are only few studies on the distribution of $5 \mathrm{~S}$ rDNA clusters in Labridae, this impairing a reliable comparative analysis.

In spite of the scarcity of cytogenetic data about Scarinae, the currently available reports suggest that repeated pericentric inversions and centric fusions have taken place during the evolutionary history of this subfamily. Such a divergent karyotypic trend in relation to other marine Perciformes might have been favored by vicariance events combined with habitat differentiation and specialization of parrotfishes (Bernardi et al., 2000; Robertson et al., 2006). To test this hypothesis, additional cytogenetic analyses in other Scarinae representatives are highly encouraged.

Finally, the present study challenges the traditional view of conserved chromosomal patterns in marine Perciformes, which, to our view, represents an overstatement caused by limited data. In addition, the combination of chromosomal analyses and DNA barcoding have proven to be an efficient strategy to identify sibling or morphologically very similar species, as commonly observed within Sparisoma.

\section{Acknowledgments}

This study was supported by FAPESB (PNE0019/2011 and APP0064/2011), UESB, "Rede de DNA barcoding da ictiofauna do Brasil" and "INCT de Ambientes Marinhos Tropicais". Specimens were collected after authorization provided by ICMBio/SISBIO (license numbers 31360-1 and 27027-2).

\section{References}

Accioly IV, Bertollo L, Costa G, Jacobina U and Molina WF (2012) Chromosomal population structuring in carangids (Perciformes) between the north-eastern and south-eastern coasts of Brazil. Afr J Mar Sci 34:383-389.

Bellwood DR (1994) A phylogenetic study of the parrotfishes family Scaridae (Pisces, Labroidei), with a revision of genera. Rec Aust Mus 20:1-86.

Bernardi G, Robertson DR, Clifton KE and Azzurro E (2000) Molecular systematics, zoogeography, and evolutionary ecology of the Atlantic parrotfish genus Sparisoma. Mol Phylogenet Evol 15:292-300.

Feitoza BM, Rosa RS and Rocha LA (2005) Ecology and zoogeography of deep-reef fishes in Northeastern Brazil. Bull Mar Sci 76:725-742. 
Galetti Jr PM, Molina WF, Affonso PRAM and Aguilar CT (2006) Assessing genetic diversity of Brazilian reef fishes by chromosomal and DNA markers. Genetica 126:161-177.

Gasparini JL, Joyeux JC and Floeter SR (2003) Sparisoma tuiupiranga, a new species of parrotfish (Perciformes, Labroidei, Scaridae) from Brazil, with comments on the evolution of the genus. Zootaxa 384:1-14.

Hatanaka T and Galetti Jr PM (2004) Mapping the 18S and 5S ribosomal RNA genes in Prochilodus argenteus Agassiz, 1829 (Characiformes, Prochilodontidae). Genetica 122:239-244.

Hebert PDN, Cywinska A, Ball SL and Waard JR (2003) Biological identifications through DNA barcodes. Proc R Soc Lond Biol Sci 270:313-321

Helfman GS, Collette BB, Facey DE and Bowen BW (2009) The Diversity of Fishes. 2nd edition. Wiley Blackwell, Oxford, $720 \mathrm{pp}$.

Howell WM and Black DA (1980) Controlled silver staining of nucleolus organizer region with protective colloidal developer: A 1-step method. Experientia 36:1014-1015.

Hubert N, Delrieu-Trottin E, Irisson JO, Meyer C and Planes S (2010) Identifying coral reef fish larvae through DNA barcoding: A test case with the families Acanthuridae and Holocentridae. Mol Phylogenet Evol 55:1195-1203.

Jacobina UP, Vicari MR, Bertollo LAC and Molina WF (2012). Discriminatory profile of rDNA sites and trend for acrocentric chromosome formation in the genus Trachinotus Lacépède, 1801 (Perciformes, Carangidae). Comp Cytogenet 6:359-369.

Lima-Filho PA, Cioffi MB, Bertollo LAC and Molina WF (2012) Chromosomal and morphological divergences in Atlantic populations of the frillfin goby Bathygobius soporator (Gobiidae, Perciformes). J Exp Mar Biol Ecol 434:63-70.

Levan A, Fredga K and Sandberg AA (1964) Nomenclature for centromeric position on chromosomes. Hereditas 52:201-220.

Mandrioli M, Colomba MS and Vitturi R (2000) Chromosomal analysis of repeated DNAs in the rainbow wrasse Coris julis (Pisces, Labridae). Genetica 108:191-195.

Martins C and Galetti Jr PM (2001) Organization of 5S rDNA in species of the fish Leporinus: Two different genomic locations are characterized by distinct nontranscribed spacers. Genome 44:903-910.

Martins C and Wasko AP (2004) Organization and evolution of $5 \mathrm{~S}$ ribosomal DNA in the fish genome. In: Williams CR (ed) Focus on Genome Research. Nova Science Publishers, Hauppauge, pp 335-363.

Martins C, Ferreira IA, Oliveira C, Foresti F and Galetti Jr PM (2006) A tandemly repetitive centromeric DNA sequences of the fish Hoplias malabaricus (Characiformes, Erythrinidae) is derived from $5 \mathrm{~S}$ rDNA. Genetica 127:133-141.

Martins C, Cabral-de-Mello DC, Valente GT, Mazzuchelli J and Oliveira SG (2011) Cytogenetic mapping and its contribution to the knowledge of animal genomes. In: Kevin VU (ed) Advances in Genetics Research. Vol. 4. Nova Science Publishers, Hauppauge, pp 1-82.

Medrado AS, Ribeiro MS, Affonso PRAM, Carneiro PLS and Costa MA (2012) Cytogenetic divergence in two sympatric fish species of the genus Astyanax Baird and Girard, 1854 (Characiformes, Characidae) from northeastern Brazil. Genet Mol Biol 35:797-801.

Molina WF, Costa GWWF, Cioffi MB and Bertollo LAC (2012a) Chromosomal differentiation and speciation in sisterspecies of Grammatidae (Perciformes) from the Western Atlantic. Helgoland Mar Res 66:363-370.

Molina WF, Mota-Neto CC, Sena DSC, Cioffi MB and Bertollo LAC (2012b) Karyoevolutionary aspects of Atlantic hogfishes (Labridae-Bodianinae), with evidence of an atypical decondensed argentophilic heterochromatin. Mar Genomics 6:25-31.

Motta-Neto CC, Cioffi MB, Bertollo LAC and Molina WF (2011a) Molecular cytogenetic analysis of Haemulidae fish (Perciformes): Evidence of evolutionary conservation. J Exp Mar Biol Ecol 407:97-100.

Motta-Neto CC, Cioffi MB, Bertollo LAC and Molina WF (2011b) Extensive chromosomal homologies and evidence of karyotypic stasis in Atlantic grunts of the genus Haemulon (Perciformes). J Exp Mar Biol Ecol 401:75-79.

Moura RL, Figueiredo JL and Sazima I (2001) New taxa paper a new parrotfish (Scaridae) from Brazil, and revalidation of Sparisoma amplum (Ranzani, 1842), Sparisoma frondosum (Agassiz, 1831), Sparisoma axillare (Steidanchner, 1878) and Scarus trispinosus. Bull Mar Sci 68:505-524.

Netto MRCB, Pauls E and Affonso PRAM (2007) A standard protocol for obtaining fish chromosomes under post-mortem conditions. Micron 38:214-217.

Parenti P and Randall JE (2011) Checklist of the species of the families Labridae and Scaridae: An update. Smith Bull 13:29-44.

Pendás AM, Morán P and García-Vásquez E (1993) Multi-chromosomal location of ribosomal RNA genes and heterochromatin association in brown trout. Chromosome Res 1:63-67.

Pinheiro HT, Gasparini JL and Sazima I (2010) Sparisoma rocha, a new species of parrotfish (Actinopterygii, Labridae) from Trindade Island, South-western Atlantic. Zootaxa 2493:59-65.

Pinkel D, Straume T and Gray JW (1986) Cytogenetic analysis using quantitative high-sensitivity, fluorescence hybridization. Proc Natl Acad Sci USA 83:2934-2938.

Robertson DR, Karg F, Moura LR, Victor BC, Bernardi G and Moura RL (2006). Mechanisms of speciation and faunal enrichment in Atlantic parrotfishes. Mol Phylogenet Evol 40:795-807

Rocha LA, Brito A and Robertson DR (2012). Sparisoma choati, a new species of Parrotfish (Labridae, Scarinae) from the tropical eastern Atlantic. Zootaxa 3152:61-67.

Schultz LP (1958) Review of the parrotfishes, family Scaridae. Bull U S Natl Mus 214:1-143.

Schweizer D (1980) Simultaneous fluorescent staining of Rbands and specific heterochromatic regions (DA/DAPI bands) in human chromosomes. Cytogenet Cell Genet 27:190-193.

Sena DCS and Molina WF (2007a) Robertsonian rearrangements and pericentric inversions in Scaridae fish (Perciformes). Genet Mol Res 6:575-580. 
Sena DCS and Molina WF (2007b) Chromosomal rearrangements associated with pelagic larval duration in Labridae (Perciformes). J Exp Mar Biol Ecol 353:203-210.

Streelman JT, Alfaro M, Westneat MW, Bellwood DR and Karl SA (2002) Evolutionary history of the parrotfishes: Biogeography, ecomorphology, and comparative diversity. Evolution 56:961-971.

Sumner AT (1972) A simple technique for demonstrating centromeric heterochromatin. Exp Cell Res 75:304-306.

Tamura K, Peterson D, Peterson N, Stecher G, Nei M and Kumar S (2011) MEGA 5: Molecular evolutionary genetics analysis using maximum likelihood, evolutionary distance, and maximum parsimony methods. Mol Biol Evol 28:27312739.

Valdez-Moreno M, Vásquez-Yeomans L, Elías-Gutiérrez M, Ivanova NV and Hebert PDN (2010) Using DNA barcodes to connect adults and early life stages of marine fishes from the Yucatan Peninsula, Mexico: Potential in fisheries management. Mar Freshwater Res 61:655-671.
Ward RD, Zemlak TS, Innes BH, Last PR and Hebert PDN (2005) DNA barcoding Australia's fish species. Philos Trans R Soc B Biol Sci 360:1847-1857.

Weigt LA, Baldwin CC, Driskell A, Smith DG, Ormos A and Reyier EA (2012) Using DNA barcoding to assess Caribbean reef fish biodiversity: Expanding taxonomic and geographic coverage. PLoS One 7:e41059.

Westneat MW and Alfaro ME (2005) Phylogenetic relationships and evolutionary history of the reef fish family Labridae. Mol Phylogenet Evol 36:370-390.

Veneza I, Felipe B, Oliveira J, Silva R, Sampaio I, Schneider H and Gomes G (2013) A barcode for the authentication of the snappers (Lutjanidae) of the western Atlantic: rDNA 5S or mitochondrial COI? Food Control 38:116-123.

Associate Editor: Yatiyo Yonenaga-Yassuda

License information: This is an open-access article distributed under the terms of the Creative Commons Attribution License, which permits unrestricted use, distribution, and reproduction in any medium, provided the original work is properly cited. 